\title{
Correction to: Societal importance of Antarctic negative feedbacks on climate change: blue carbon gains from sea ice, ice shelf and glacier losses
}

\author{
D. K. A. Barnes ${ }^{1}$ - C. J. Sands ${ }^{1} \cdot$ M. L. Paulsen ${ }^{3} \cdot$ B. Moreno ${ }^{4} \cdot$ C. Moreau ${ }^{5} \cdot$ C. Held ${ }^{6} \cdot$ R. Downey $^{7} \cdot$ N. Bax ${ }^{8} \cdot$ J. S. Stark $^{2}$. \\ N. Zwerschke ${ }^{1}$
}

Published online: 11 October 2021

๑) Springer-Verlag GmbH Germany, part of Springer Nature 2021

\section{Correction to: The Science of Nature (2021) 108:43 \\ https://doi.org/10.1007/s00114-021-01748-8}

In this article, all of the authors have a " 2 " by their name affiliating them to Australian Antarctic Division. Only J. S. Stark should however be affiliated to this institution.

Also, J. Stark's middle initial was added to his name making it now read as "J. S. Stark".

The original article has been corrected.
Publisher's note Springer Nature remains neutral with regard to jurisdictional claims in published maps and institutional affiliations.

The online version of the original article can be found at https:// doi.org/10.1007/s00114-021-01748-8

\footnotetext{
D. K. A. Barnes

dkab@bas.ac.uk

British Antarctic Survey, NERC, Cambridge, UK

2 Australian Antarctic Division, Hobart, Australia

3 Aarhus Universitet, Aarhus, Denmark

4 Universidad Científica del Sur, Lima, Peru

5 Université Libre de Bruxelles, Brussels, Belgium

6 Alfred Wegner Institute, Bremerhaven, Germany

7 Australian National University, Canberra, Australia
}

8 South Atlantic Environmental Research Institute, Stanley, South Atlantic, Falkland Islands 